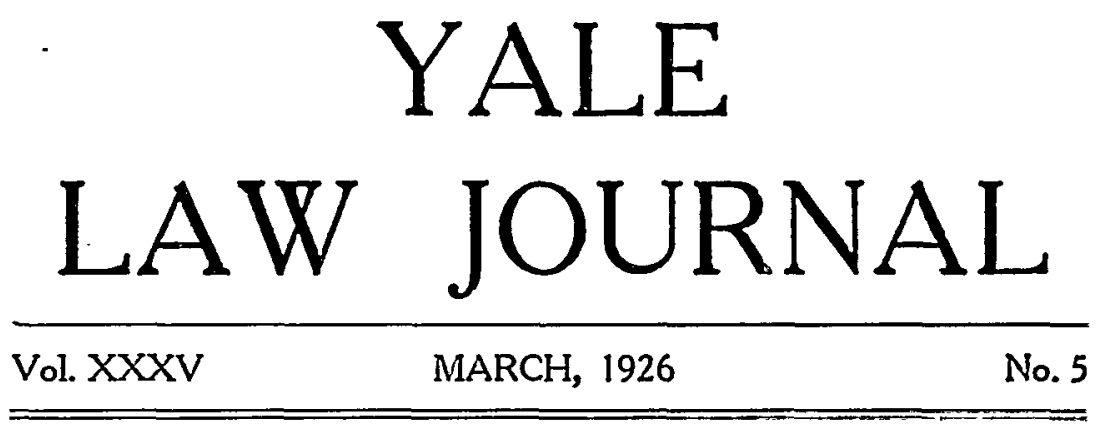

\title{
THE PRIVILEGE TO PROTECT PROPERTY \\ BY DANGEROUS BARRIERS AND MECHANICAL DEVICES
}

\section{FrANCIS H. BOHLEN and JOHN J. BURNS}

The interest which a possessor of property has in its exclusive possession is of sufficient importance to give him a privilege to use force to protect it from unprivileged intrusion. The amount of force which a possessor of property may use to exclude or expel an unprivileged intruder ${ }^{1}$ varies with the nature of the intrusion and the resistance which the intruder makes to the possessor's effort to exclude or expel him. If the intrusion obviously threatens no harm either to the physical condition of the property or to the bodily security of its possessor and those who occupy it or use it with his permission, the possessor is privileged to use only the mildest of force except to overcome the intruder's resistance to his exclusion or expulsion." If, on the other hand, the intrusion is such as to give the possessor reasonable ground to believe that it will cause death or serious bodily harm to him or to those occupying or using the property with his permission, he may prevent or terminate it by a force which is intended or likely to cause death or serious bodily injury to the intruder,

\footnotetext{
1 The term "intruder" is used to describe one who enters upon premises, or meddles with a chattel which is in the possession of another without the other's consent. The term "trespasser" includes only those who enter or meddle not only without the consent of the possessor, but also without some privilege of their own to do so. It is convenient to have a particular word to indicate the fact that the person entering premises or meddling with a chattel is doing so without the possessor's consent, irrespective of whether the entering or meddling is, or is not, privileged.

2 The phrase molliter manus imposuit, as used in the old forms of pleading, indicates the limitation on this privilege to expel intruders. Collins $v$. Renison (1754, K. B.) I Sayer, 138.
} 
if his intrusion cannot be otherwise prevented or terminated. The possessor is required to warn the intruder to desist from his intrusion before he is privileged to use any force, unless such a warning would be obviously futile or would be dangerous to the life or property of the possessor or those who are upon the premises or using the chattel with his permission. ${ }^{4}$

The possessor, if present at the time and place of intrusion, may protect his property and yet make these fine discriminations. But it is often practically impossible for a possessor of property to protect it from intrusion in person or by deputy. Whether the property be real or personal, its possessor cannot always be expected to be in occupation or custody of it. If the property is an extensive tract of land, the possessor, even if he is occupying it, is obviously incapable of patrolling its boundaries in person or by deputy so constantly as to be always at every point at which an intruder may enter. Therefore, if the property is to be protected from intrusion, it must be by some means other than human beings. But any such method of protection, whether by barriers, mechanical devices, or animals, is incapable of making those discriminations which the owner or his deputy, were he present, would be required to make and of giving a warning which the owner would often be required to give. A barbed wire fence, spiked railing, or spring gun cannot distinguish between a lawful visitor and an unprivileged intruder, and even a watchdog is capable of recognizing only the most frequent of lawful visitors. Such a means of protection may therefore be expected to operate not only against those whom the possessor. is privileged forcibly to exclude or expel, but also against those whose entry the possessor could not resist or terminate by any force, however small. Nor can these means of protection choose the precise degree of force which is appropriate to resist the particular intrusion threatened or give the warning which the possessor is often required to give before applying force.

In every privilege given for the protection of any of the actor's interests, a sharp distinction is drawn between the conditions

${ }^{3}$ Bray v. State (1918) 16 Ala. App. 433, 78 So. 463 . Despite the frequent statements by text writers that "a man's house is his castle", from which phrase they deduce the broad rule that a homicide committed to provent an unlawful entry into one's castle is "justified", it is clear that the use of dangerous weapons is privileged only if the actor reasonably fears for the safety of the life or limb of himself or of some inmate of his houso [State v. Mills (1908, Del.) 6 Penn. 497, 69 Atl. 841; State v. T'aylor (1897) 143 Mo. 150, 44 S. W. 785; Stoneman v. Commonwealth (1874, Va.) 25 Gratt. 887; State v. Patterson (1873) 45 Vt. 308], or, in some jurisdictions, if the intrusion is or is reasonably believed to be for the purpose of committing a felony although it is not one involving any such danger. Thompson v. State (1901) 61 Neb. 210, 85 N. W. 62.

4 Polkinhorn v. Wright (1845) 8 Q. B. 197; cf. Harrison v. Harrison (1871) 43 Vt. 417 . See Cooley, Torts (2d ed. 1888) 194. 
that create a privilege to use force which, while intended or likely to cause some substantial bodily injury, does not threaten death or "serious" bodily injury and the conditions which create a privilege to use force threatening such grave results." Admittedly the distinction between "substantial" and "serious" bodily injury is far from definite and clear-cut. ${ }^{\circ}$ It is easy to distinguish merely trivial harm from serious bodily injury; but it is also easy to imagine injuries which are difficult to classify as being substantial or serious. " To object, however, to a distinction based upon so vague a classification would be to hold objectionable not only a vast number of distinctions which are admittedly valid in the law of torts, but also distinctions which are valid in other fields of law. In the law of torts much must necessarily be left to the common sense and judgment of court and jury, whose function it is to administer the necessarily vague general principles of tort law and to reduce them, sometimes perhaps in rather a haphazard fashion, to that particularity necessary for their application to the infinitely varying circumstances which come before courts for decision." Not only is this distinction recognized by the law of torts in determining the existence of the majority of privileges to invade intentionally legally protected interests of personality; but it has been sanctioned by its adoption in statutory enactments, and its validity in this particular field is attested by the fact that it was expressly recognized in the English Act ${ }^{3}$ which forbade the use of mechanical devices such as spring guns

s Thus, in resisting a "simple" assault, the actor may use reasonable force but may not use force dangerous to life or limb [Cool v. Bcal (1697, K. B.) $1 \mathrm{Ld}$. Raym. 176], although he may do so if an attack involves a similar danger to him. Green v. Commonzealth (1918) 122 Va. 862, 94 S. E. 940. So, too, one may resist an unlawful arrest but is not privileged to do so by a "deadly" weapon even though the arrest can be prevented in no other way. Coats $\%$ State (1911) 101 Ark. 51, 141 S. W. 197; State v. Meyers (1910) 57 Or. 50, 110 Pac. 407; State i. Clarl: (1909) 64 W. Va. 625, 63 S. E. 402; Noles $v$ State (1855) 26 Ala. 31. But see Simmerman v. State (1883) $14 \mathrm{Neb} .568,17 \mathrm{~N}$. W. 115; and see Wharton, Homicide (2d ed. 1878) sec. 227.

' Compare Lawlor v. People (1874) 74 Ill. 228 and Shires v. Boggcss (1913) 72 W. Va. 109, 77 S. E. 542 with Accrs 2 . United States (1890) 164 U. S. 388; Re. v. Aleenhead (1816, C. P.) Holt N. P. Cas. 469; and see State v. Kaliaritios (1915) 45 Utah, 470, 146 Pac. 750; Rogcra v. State (1894) 60 Ark. 76, 29 S. W. 894; People 2. Troy (1893) 96 Mrich. 530, 537, 56 N. W. 102, 104.

- Compare Murphy v. State (1894) 43 Neb. 34, 61 N. W. 491 with Smith v. State (1899) 58 Neb. 531, 78 N. W. 1059; and see R૯z v. Coz (1818) R. \& R. Cr. Cas. 362; and State v. Davis (1913) 72 Wash. 261, 130 Pac. 95.

* See Bohlen, Miced Questions of Law and Fact (1924) 73 U. PA. L. REv. 111.

- (1827) 7 and 8 Geo. IV, c. 18, repealed and later substantially reenaeted (1861) 24 and 25 Vict. c. 95 , sec. 1 ; and c. 100 , sec. 31. 
except for the protection of dwelling houses, and then only upon adequate notice.

Apart from this authority, it would seem clear that no interest which is merely one of property can be equal or superior to the interest which both the individual and society have in life and limb. If we look no further than to the individuals concerned, the value of the two interests are grossly disproportionate. If the interest of society is taken into account, as it must be, it is clear that society has a vital interest in the efficiency of its citizens both as fighting men and workers, which is clearly different in kind and not merely in degree from that which it has in the preservation of property from intrusion and even from harm or destruction.

Any discriminating means of protecting property from intrusion may therefore be roughly divided into those which, while intended to cause some bodily harm, are neither intended nor likely to cause death or serious bodily injury, and those which are intended or likely to cause death or serious bodily injury. Watchdogs differ greatly in size and ferocity and therefore may fall within either class.

The consideration of the responsibility of a possessor using indiscriminating means of protecting his property is therefore divided into three parts; the first dealing with the use of barriers and mechanical devices which threaten less than serious bodily injury; the second, the use of mechanical devices which threaten serious bodily injury or death; and the third, the use of watchdogs..$^{10}$

\section{I}

It is universally admitted that ordinary walls and fences, even so high that persons attempting to scale them may be injured if they fall therefrom, are privileged means of protecting property from intrusion, but such barriers are generally insufficient protection against determined intrusion. Therefore, additional protection is often added by placing broken glass on the top of a wall, putting spikes upon railings, or making a fence of barbed wire. Such additional safeguards contain an actual probability of inflicting upon intruders injuries which the possessor, were he present in person, could inflict only on rare occasions, and upon a comparatively small number of trespassers; and they always operate without that immediate warning which the possessor must give, save in exceptional cases, before acting. Such barriers may affect not only deliberate intruders, irrespective of the purpose and circumstances of their intrusion, but they may also, although far less probably, affect persons who come upon the

10 This last division will be treated in a separate article, the present article dealing only with the first two. 
premises at the occupier's invitation or permission or in the exercise of a privilege of their own. There is at least a slight chance that a dangerous fence or railing may affect the safety of persons who come in contact with it while in the lawful use of adjacent property, or by some unavoidable or childish deviation while lawfully traveling upon an adjoining highway. There is also a possibility that these devices may injure cattle lawfully straying or being driven on the highway.

No case, either English or American, decides or even intimates that an owner of property is liable to a trespasser who is injured by coming in contact with such a barrier, no matter how harmless may be his intrusion. In the one American case ${ }^{11}$ in which the question is presented for decision, it was held that an owner of land who, to protect it from being used as a shortcut, had erected thereon a barbed wire fence, was not liable to a person who was injured by it while attempting to cross the owner's property without his permission.

Trespassers are the very persons whose intrusions such dangerous barriers are intended to deter and resist. In so far as concerns trespassers whatever their purpose, the action of such devices differ from that of a human guardian in that they are incapable of gauging the exact amount of force which it is permissible to apply to the various classes of trespassers who may intrude, and in that they cannot give the warning to desist from the intrusion which a human being is generally required to give immediately before acting. There is, therefore, the certainty that they will act without warning and the chance that they will inflict upon merely harmless trespassers an injury which is slightly in excess of that which under the actual, or even under the apparent circumstances, the possessor or his human deputy would be privileged to inflict.

In the daytime spiked railings and barbed wire fences carry their own warning unless concealed, as for example, by a hedge. Broken glass on a high wall may not be noticed by a trespasser until he places his hand upon it and is injured by it. Neither are spiked railings nor barbed wire fences visible at night. But if such walls, fences and railings are customary, as they are in many localities, a trespasser, though he may not know of their existence, knows that they may exist. To trespassers by night, the

${ }^{11}$ Quigley v. Clough (1899) 173 Miass. 429, 53 N. E. 884. Holmes, J., says, "Barbed wire is well known and has been widely used for fencing as more efficient than common wire. . . . It is and has been a common article of commerce and the use of it simply shows an intent to malie it more difficult to pass the line of fence."

By statute in Missachusetts it is provided that "No barbed wire fence shall be built or maintained within six feet above the ground along any sidewalk located on or upon any public street or highway". See IIass. Gen. Laws, 1921, ch. 86, sec. 6. 
notoriety of their customary use supplies the place of knowledge which trespassers by day obtain by their senses. ${ }^{12}$ Not only does the knowledge of the existence of such fences or railings, or the knowledge that they are customarily used and so may be expected, serve as a warning in advance, which may well be taken to supply the place of the warning which the occupier must generally give immediately before acting, but it has a further value. It acts as a deterrent to all but the most persistent of trespassers who are willing to take a chance of the slight injury rather than abandon the purpose to violate the occupier's property rights. It also goes to show that the owner's purpose is not to injure trespassers when they intrude, but to protect his property not only by the resistance which these fences and wires make to unauthorized entry, but by the deterrent force which they will exercise. If the device is not customary, it would seem that at least as far as concerns responsibility to a person injured while trespassing, the occupier must take at least all reasonable steps to bring home notice of its use to all those persons whom he has reason to expect to trespass upon his property. Unless such notice is given, the device can have no deterrent effect; and the failure to give such a notice, if it be deliberate, tends to show that the purpose in installing it is not merely to prevent intrusion but in part at least to injure such persons as may intrude.

The injury which such barriers can do is, after all, not severe and is therefore only slightly in excess of that which the occupier. could personally or by deputy inflict upon even a harmless trespasser. The slight chance of the deterrent force of the knowledge of the existence of the fence, or of the lnowledge that such fences are customary and therefore to be expected, will

12 If the device is unusual, the occupier is so far privileged to use it that he is not liable to intruders if the injury which it is intended or likely to inflict is less than death or serious bodily injury, and is not dis. proportionately great as compared with the value of the property interest which the device is necessary to protect, and a reasonably sufficiont warning of its use is brought home to all those likely to intrude and thereby come in contact with it.

In so far as concerns persons lawfully upon premises or traveling upon highways upon which the premises abut, the absence of warning goes principally to show that the device is not a reasonable or proper means of protecting the property. So far as adult travelers are concerned, knowledge of the device would be of no avail to them, since the owner is not liable to them no matter what the condition of his property unless tho travelers' deviation thereon is accidental and unintentional. A warning may be of some value as a deterrent and so a protection to children who are entitled to protection from dangers which their immaturity prevents them from observing, even during a deliberate but expectable deviation. And an adjoining owner is entitled to such a warning of even the most necessary and reasonable conditions on the premises, so that he may take the necessary precautions to minimize their danger to his use of his own property. 
be insufficient to prevent trespasses. Furthernore, the chance that a trespasser who is willing to run the risk involved in such barriers will be a harmless trespasser against whom the possessor is privileged to use only the slightest force is so slight as compared with the practical importance of otherwise protecting the property from intrusion that it seems entirely proper for courts to permit, as they do, the use of such means of protection without responsibility to any class of trespassers for the slightly excessive injury which they may occasionally inflict.

There is no case which even discusses the liability of an occupier who protects his property by such barriers to persons coming in contact with these devices while entering the premises by his invitation or permission, or in the exercise of a privilege of their own to enter irrespective of his consent. This fact shows the extreme improbability that one entering premises at the possessor's invitation or with his permission, or even in pursuance of a custom, local or general, such as is often held to confer a privilege analogous to the license given by express consent, will be affected by such barriers. A person entering another's premises, whether by invitation and for the purpose of the owner's business, or by permission and for his own purposes, is entitled to be informed of only such dangers as lurk in that part of the premises which is included within the area of his license; and unless permission is given to climb a fence or scale a wall or railing, a licensee, whether by invitation, permission or local custom, is entitled to enter only at those points which the owner has caused or permitted to appear to be the prepared approaches to his premises. ${ }^{13}$

${ }^{13}$ Gardner v. Roland (1842, N. C.) 2 Ired. 247; see Ecdell a. Bcrlicy (1889) 76 Mich. 435, 439, 43 N. W. 308. In Mazcy 2. Loucland (1916) 123 Minn. 210,158 N. W. 44 , the plaintiff, who had come to the defendant's residence on business and at his invitation, on leaving attempted to cross the lawn to reach her automobile instead of leaving by the wall: leading to the street, and was injured by tripping over a wire stretehed at the height of two feet from the ground, for the purpose of protecting the lawn from being used as a short-cut.

The court in its opinion incidentally states that "the prezence of the wire was not inherently dangerous, and that such barriers are usual and frequently erected in this or some other form to prevent passage over private lawns", but bases its decision in favor of the defendant upon the fact that "from the moment the plaintiff abandoned the ordinary exit and chose to cross the lawn, she became a mere licensee." A part of the opinion seems to deny the existence of any duty to warn a mere licensee of a danger of which the owner is aware, but in a later part of the opinion attention is called to the fact that "it was not so dark that the wire could not have been seen by the exercise of ordinary care, and the facts shown in the record are not sufficient to justify the conclusion that the defendant (who was present) knew, or had any reason to believe, that if the plaintiff continued to cross the lawn, she was at all liable to trip or fall over the wire." The case, therefore, goes no further than to hold that an 
One entering in pursuance of a privilege is entitled at most to find the ordinary approaches safe for his entry. ${ }^{14}$ Such persons therefore, if they choose to enter at unusual places, are outside the area of their license or privilege and are therefore as much trespassers as though they had no license or privilege. ${ }^{10}$ No case has arisen in which a prepared entrance has been blocked by dangerous barriers. If such a case should arise, it would seem that the owner should be liable unless he brought home to the licensee or privileged entrant this unusual method of protecting his property.

Where human oeings or livestock lawfully traveling upon an adjoining highway come in contact with the fences or railing by some expectable and innocent deviation, there appears at first glance an analogy to the numerous cases in which it is held that a possessor of property who maintains an excavation or other dangerous condition immediately adjacent to an adjoining highway is liable to human beings and cattle so falling therein or coming in contact therewith. ${ }^{10}$

owner of property, even if present, is not bound to warn a mere licensee of a danger of which he has no reason to believe that the licensee is ignorant. It does not align the Minnesota Court with those jurisdictions which hold that an owner may without liability allow a person, who entors his premises relying upon the permission extended to him, to stumble unawares into a danger which the owner knows the licensee neither expects nor is likely to observe, and of whose presence the owner could without undue trouble warn him. As to this, see Bohlen, Landowner's Duty to Those Entering His Premises of Their Own Right (1921) 69 U. PA. L. REv. 340, 353-6, and compare with the cases cited therein Habina v. Twin City Gen. Elec. Co. (1907) 150 Mich. 41, 113 N. W. 586, and Martin v. Louisville etc. Bridge Co. (1908) 41 Ind. App. 493, 84 N. T. 360.

${ }^{14}$ See Bohlen, op. cit. supra note 13, at 142, 237, 340; and Steinvodol $v$. Hilbert (1925, Md.) 131 Atl. 44.

15 The courts show a curious tendency to speak of an invitee, who goes outside of the area into which he is invited to enter, as thereby becoming a licensee. See Mazey v. Loveland, supra note 13; and Powers v. Raymond (1925, Calif.) 239 Pac. 1069. This may not be important in those jurisdictions which deny that a landowner is under any greater obligation to a bare "licensee" than he is to the most flagrant of trespassers. But it ceases to be a mere error of form and becomes a matter of practical importance in those jurisdictions which properly place upon an owner of real estate the same duty to disclose any dangerous defect therein of which he knows to one whom he may expect to enter in ignorance of its existence, and in reliance upon the good faith of no matter how gratuitous a permission to enter, as substantially all jurisdictions impose upon an owner of a chattel who gratuitously permits another to use it. So too, it becomes an error of substance in a jurisdiction which recognizes that an owner who has given another permission to enter his premises for any purpose must expect the permission to be utilized, and is therefore bound to refrain from acts which may unduly imperil his licensee if he enters. See Bohlen, op. cit. supra note 13, at 243, 248, 353-6.

${ }^{26}$ Barnes v. Ward (1850, C. P.) 9 C. B. 392; Ruocco v. United Adv. Co. (1922) 98 Conn. 241, 119 Atl. 48; Smith v. Milford (1914) 89 Conn. 24, 
Even those jurisdictions which have not adopted the doctrine of the turntable cases tend to recognize the common practice of young children to make considerable deviations from the traveled way, and require occupiers of premises abutting upon highways to regulate their use thereof so as not to make such childish deviations unduly dangerous. ${ }^{17}$ Thus certain areas contiguous to highways have become taboo to uses dangerous to children. So too, the well-known tendency of cattle to stray is recognized, at least in some jurisdictions, as casting upon owners of property which abut upon highways the duty to lieep so much of their property as is immediately adjacent thereto free from conditions unnecessarily dangerous to eattle. ${ }^{1 / 3}$ But neither adult nor child wayfarers nor the owners of livestock lawfully in a highway are entitled to find the adjacent premises absolutely safe for their unavoidable or innocent deviations. They are only entitled to find the premises reasonably safe; and in determining whether the occupier is, or is not, keeping his premises in a reasonably safe condition for such deviations, the occupier's interest in the use of his premises is to be weighed against the danger to travelers, old and young.

In the cases in which the owner has been held liable, the dangerous condition, generally an excavation though sometimes a structure or appliance erected or maintained upon the premises, was not necessary to the owner's use of his property, or it was not necessary to maintain it at a point adjacent to the highway or in the condition which made it dangerous-or, if necessary at that point and in that condition, it might have been made innocuous by guards or railings without substantially interfering with its utility. ${ }^{19}$ Even a use of the premises whose dangerous effects

92 Atl. 675. See also Becli v. Cartcr (1877) GS N. Y. 283; Mrurphy v。 Bolger (1888) 60 Vt. 23; contra: Howland v. Vincent (1815) 51 Mass. 371.

There is some difference of opinion as to what constitutes an unavoidable and so an innocent deviation by an adult traveler and the propinquity of the dangerous condition to the highway which is requisite to create liability. See (1924) 38 HARv. L. Rev. 265. It is not necessary to discuss these questions. In the few cases in which adult travelers hare been injured by barbed wire or spiked railings, the facts were such as to bring the case within the narrowest view on both points.

${ }_{17}$ Cf. Ruocco v. United Adv. Co., supra note 16. In Grogan v. Sclcle (1885) 53 Conn. 186, 1 Atl. 899, the plaintiff was injured by folling into an unguarded area adjoining the public highway. The court in holding the defendant liable emphasized the fact that the paving of the area in the defendant's yard was of the same material as that used in paving the sidewalk so that as a result the fence line was not indicated. This, said the court, constituted an allurement. See also Duffcy v. Sable Iron Wrarlso (1904) 210 Pa. 326, 59 Atl. 1100; Birge v. Gardince (1S49) 19 Conn. 506.

18 Powell v. Salsbury (1828, Exch.) 2 Y. \& J. 391; cf. Serton v. Bacen (1859) 31 Vt. 540.

${ }^{19}$ Lepnick v. Gaddis (1894) 72 Miss. 200, 16 So. 213; Ovcrholt v. Ticths (1888) 93 MIo. 422, 6 S. W. 74. See Dobbizs v. Missouri R. R. (1397) 01 Tex. $60,65,41$ S. W. 62,64 . 
extend beyond the premises themselves and render travel dangerous to wayfarers who confine themselves to the highway is not unreasonable if the use is one which is essential to the occupier's business and is so conducted as to create no unnecessary danger. ${ }^{20}$ In none of the cases in which the occupier of premises abutting upon a highway was held liable, was the dangerous condition maintained by the owner of the property as a means of protecting it from intrusion. And it is submitted that no distinction can be drawn between a condition which is necessary for the protection of the premises from intrusion and a condition which is necessary for the owner's business or other use of his premises.

But in the one case as in the other the condition must be not only necessary to serve the occupier's purposes, but it must be so constructed as to contain no dangers which are not necessary to accomplish that purpose. A barbed wire fence properly strung necessarily contains some risk of injury to persons or cattle who come in contact with it. But the injury which a fence so constructed can do is comparatively trivial. The presence of a railing gives warning of the existence of the fence and prevents it from operating as a trap or hidden danger, ${ }^{21}$ even to a child, if old enough to travel unattended, or to livestock. This, together with the slight chance of innocent deviation, makes the total risk insignificant as compared with the occupier's interest in preserving his property from intrusion, which he cannot otherwise effectively do. If, however, a barbed wire fence is so loosely strung as to make it likely to entangle either human beings or cattle, the injury which it threatens is seriously increased. The absence of a top railing or the excessive distance between the posts to which it is strung may prevent either children or cattle from observing it, and so lead them unwittingly to come in contact with it in the course of their innocent, though intentional and perhaps technically illegal, deviations. There are, therefore, many cases which hold that owners of property are liable to the owners

20 See Wolf v. Des Moines Elevator Co. (1905) 126 Iowa, 659, 98 N. W. 301,102 N. W. 517.

21 Some of the statutes regulating the erection of barbed wire fences along highways provide that the fence must be topped by a board of $a$ certain thickness. See N. C. Sts. 1895, ch. 85. This is obviously not so much for the purpose of protecting human beings unintentionally and unavoidably deviating from the highway as to apprise cattle driven or lawfully straying along it of the existence of the fence into which they might otherwise stray and injure themselves. On the other hand, the Massachusetts statute prohibiting the use of barbed wire upon fences adjacent to the highway except at the height of six feet or more, is clearly intended to protect human travelers as well as cattle. See Mass. Gen. Laws, 1921, ch. 86, sec. 6; Conn. Gen. Sts. 1918, sec. 5130. In Kentucky by statute the owner of adjacent land may prevent the erection of a barbed wire devision fence. See Carrol's Ky. Sts. (6th ed.) sec. 1784. 
of cattle injured by barbed wire fences so strung as to involve an unnecessary danger; but the cases which so hold all direetly or inferentially recognize a privilege to use a barbed vire fence so constructed as to do a minimum of harm and to give a maximum of warning. 22

The privilege to use a slightly dangerous device for the purpose of preventing intrusions without liability to persons who are not intruders, and whom therefore the devices are not intended to affect, is closely analogous to the privilege of defending oneself against another's attack without liability to a third party unintentionally injured by one's' self-defensive act. ${ }^{3}$ In such a case the defendant is not liable to a third party whom he does not intend his self-defensive act to affect unless under all the circumstances he should realize that his act creates not only a probability, but an undue one, of causing injury to the third party. It is not enough that the means of defense creates some such probability. The probability must be undue. The exigency in which the defendant is placed by the attack and the value of his interest in bodily security, which he is protecting by his action, is to be considered in determining whether the means of defense which he selects is, or is not, improper. ${ }^{23}$

Thus a man who, without any necessity of so doing, fires a revolver along a vacant city street, would undoubtedly be held

22 Hurd v. Lacey (1890) 93 Ala. 427, 9 So. 378; Foster v. Swope (1889) 41 Mo. App. 137; Sisl v. Crump (1887) 112 Ind. 504, 14 N. E. 381. $C f$. Loveland v. Gardiner (1S89) 79 Calif. 317, 21 Pac. 766.

In all the cases which have absolved occupiers of property from liability for injuries caused by barbed wire fences, there is constant reference to the fact that such fences are in customary use. Occasional reference is made to the fact that if these fences involve any danger it is danger not only to persons or livestock who come in contact with them from without but also to persons and livestock coming in contact with them frorn within. The fact that the owners of the property consider the peril so slight that they do not hesitate to expose themselves and their own livestock to it is regarded as showing that the common consensus of opinion holds them not to be unreasonably dangerous. See Colo. Comp. Sts. 1921, sec. 3133, where the definition of a lawful fence specifically includes one made with barbed wire.

${ }^{3}$ Cf. Moris v. Platt (1861) 32 Conn. 75; Paxton v. Boycr (1873) 67 Ill. 132; Pollock, Torts (11th ed. 1920) ch. 4, sec. 12.

24 In Kelly v. Bennett (1890) $132 \mathrm{~Pa} .218,19$ Atl. 69, the only case in which a traveler was injured by falling against a spilied railing, the plaintiff slipped upon an icy sidewalk, and in trying to breal his fall, put out his hand which was impaled on the spilkes of a railing which the defendant had put up to guard his areaway. In reversing a judgment for the plaintiff, Paxson, C. J., said: "The railing was a lawiul structure. The defendant had a right to protect his area in this manner. Had he not done so and someone had been injured, there would have been more reason for charging him with negligence. It has been said, however, that it should have been constructed without points. This is not so clear. The points are useful in preventing mischievous boys from climbing over." 
liable if the bullet struck a person suddenly appearing from a doorway or intersecting street. But if he were defending himself against a murderous attack, he would undoubtedly not be held liable if the bullet went astray and instead of striking his assailant, struck a person who thus suddenly and unexpectedly came upon the scene.

It is certainly worthy of notice that only two cases have been brought before an appellate court in which intruders have been injured by moderately dangerous fences or devices. No case has been so brought in which a licensee or privileged intruder has been injured by such means; and of the cases in which injury has been done to persons or animals lawfully traveling upon a highway only two have been cases in which the injuries have been personal. ${ }^{25}$ In one of these the plaintiff was thrown from his horse which shied into a barbed wire fence and was made uncontrollable by the pain of the wounds which the fence inflicted upon it."

The most usual cases in which the liability for the negligent construction of such barbed wire fences has been considered have been cases in which cattle, lawfully straying or driven upon a highway, have become entangled in the loosely strung wires thereof. ${ }^{27}$ In view of the constant use of such devices and the small number of cases of injury to human beings or even to animals, it seems rash to regard such fences as containing any considerable element of danger.

II.

Save in a few jurisdictions, it is consistently held that a possessor of property is not privileged directly and in person to kill or maim to protect his property from injury or destruction, much less to protect it from mere harmless intrusion. ${ }^{28}$ Indeed, he is not privileged to do so even to prevent himself from being dis-

He also points out the extreme improbability of such an accident and the great number of circumstances which must concur to bring it about. In this case, therefore, all the elements for the privileged use of such a protection appear. The railing was necessary not only to protect the premises from intrusion, but to protect the traveling public, which it could not do if it had been erected anywhere else. There was, thereforo, no question as to the propriety of its location. The points which made the plaintiff's injury possible were a reasonable means of preventing the intrusion of mischievous boys; and the danger to legitimate travel was negligible.

${ }^{25}$ Kelly v. Bennett, supra note 24; Worthington v. Wade (1891) 182 Tex. 26,17 S. W. 520.

26 Worthington $v$. Wade, supra note 25.

27 See the cases cited supra note 22.

${ }^{28}$ Grigsby v. Commonwealth (1913) $151 \mathrm{Ky} .496,152$ S. W. 580; Bloom v. State (1900) 155 Ind. 292, 58 N. E. 81; Gardiner v. Thibodeau (1850) 14 La. Ann. 742; Harrison v. State (1854) 24 Ala. 67; of. Simpsoni v. Stato (1877) 59 Ala. 1. 
possessed of any property, real or personal, ${ }^{20}$ other than his dwelling place. ${ }^{30}$ In Ilott $v$. Wilkes, ${ }^{31}$ the Court of King's Bench made absolute a rule to enter a non-suit against a plaintiff who, with knowledge that the defendant had placed spring guns in his woods, trespassed upon the woods and was injured by a spring gun upon the wire of which he had accidentally trod. But the court admitted that one who sees another trespassing upon his land gains no privilege personally and directly to shoot the trespasser by announcing his intention to do so if the trespasser persisted in his trespass.

It is difficult to see why a trespasser should take any greater risli of injury from a spring gun set for the very purpose of injuring him, if he intrudes, than he is required to take of being shot by the owner who threatens to shoot him if he intrudes and shows every sign of a fixed intention to carry out his threat. The trespasser knows that by his own act he is exposing himself to the danger of being shot by the spring gun, but that catastrophe he means and hopes to avoid. The chance of avoiding wires which set off the spring gun is not appreciably less than the chance that the owner of the property will at the last moment relent. It is idle to seek refuge in the fiction that one cannot expect that another will do a criminal or wrongful act.32 Whatever may once have been the attitude of Anglo-American courts, there is at present a distinct tendency to hold that even criminal misconduct is sometimes to be anticipated and provided against, and this even when the intention to commit it is not lnown.:3

Apart from this, it is consistently held that one who puts himself in a position of danger, however wongfully, does not thereby forfeit all right to safety. It has never been held that contributory fault, whether of inadvertence or of deliberate choice to

29 See Stacey v. Commonwealth (1920) 189 Ky. 402, 407, 225 S. W. 37, 39.

${ }^{30}$ In re Hussey (1924, Eng.) 18 Cr. App. 160.

$3 I$ (1820, K. B.) 3 B. \& Ald. 304.

In Bird v. Holbrool: (1828 C. P.) 4 Bing. 628, the Court of Common Pleas was confronted with a situation which was discussed, without any definite expression of opinion, by the court in Ilott $v$. Willics. In that case the plaintiff, while trespassing on the defendant's garden in search of his fowl, was injured by a spring gun which the defendant had set therein without giving any warning of its presence. The court held that the plaintiff should recover. The opinion of Chief Justice Best, who tools part in the decision of Ilott $v$. Willes, regards the absence of notice as of principal importance as showing that the spring guns were not "set for the purpose of deterring" trespassers, but "for the purpose of doing injury" to anyone who might trespass upon his garden.

32 See Beale, Prosimate Consequences of an Act (1920) 33 Hnnv. L. REv. 633, 650; Bohlen, Contributory Negligence (1908) 21 HARY. L. REv. 233, 236.

33 Hall v. Smathers (1925, N. Y.) 148 N. E. 654; Mitchell v. Churches (1922) 119 Wash. 547, 206 Pac. 6; Hines v. Garrott (1921) 131 Va. 125, 108 S. E. 690; Brower v. New Yorli Cent. Ry. (1918) 91 N. J. L. 190, 103 Atl. 166; Paterson v. Norris (1914, K. B. Div.) 30 T. I. R. 393. 
encounter unnecessarily a known danger, is a defense against one who takes advantage of another's carelessness or temerity to inflict an intentional injury upon him. ${ }^{34}$ A trespasser, even if he knows of the setting of spring guns, is merely braving a danger and is not deliberately encountering a certainty of injury. His trespass expresses no such willingness to be injured as to make it amount to the giving of consent, thereto. ${ }^{35}$

If the owner is privileged to act, a warning given in advance may possibly supply the place of a warning given immediately before action; but it can give no privilege to commit so gross an excess of privilege as that of shooting in defense of a mere property interest less than the interest in the possession of a dwelling place. ${ }^{36}$ It is more than doubtful whether it is, as is sometimes supposed, a principle of the common law that one may not do indirectly that which he may not do directly. As has been seen, barbed wire fences, spiked railings and devices whose probable effect is to frighten rather than hurt, or at most to inflict merely trivial harm, may be used without liability even though the trespasser injured thereby has no harmful purpose, and the owner, if he were present in person, would not be privileged to inflict even' so trivial an injury upon him. The danger that such a fence or device may inflict a bodily harm slightly in excess of that which the owner might inflict, if he were present in person, is counterbalanced by the impracticability of otherwise protecting the property from intrusions, whether harmless or harmful.

The decision in Illot $v$. Willes aroused such a storm of protest in England ${ }^{37}$ that it was abrogated seven years later by a stat-

34 See Bohlen, loc. cit. supra note 32.

35 This is the thought of Salmond in his criticism of Ilott $v$. Willes. "It seems an anomalous and incorrect application of the maxim 'volenti non fit injuria'. If a man intentionally shoots me, am I debarred from an action because I knew of his intention and faced the risk? Am I guilty of contributory negligence and so deprived of redress because I fail to take sufficient care to avoid a mischief which another has wilfully sought to inflict upon me?" See Salmond, Torts (6th ed. 1924) 453.

${ }^{36}$ In addition, or perhaps as an elaboration of the argument that the plaintiff took upon himself the risk of injury when he trespassed upon the defendant's wood knowing that spring guns were set therein, Holroyd, J., says at page 314-315, "If the plaintiff had express notice that spring guns were placed on the premises which ho unlawfully entered - . . the act of firing off the gun; which was the cause of the injury, was his act and not the act of the person who placed the guns there, although this would not be so if the plaintiff had not known that tho gun had been set." A similar thought is expressed by Alderson, B., in Jordin v. Crump (1841, Exch.) 8 M. \& W. 782, at 788. The fallacy of this argument is sufficiently exposed by Butler, J., in Johnson v. Patterson (1840) 14 Conn. 1, 8-9.

${ }^{37}$ See 10 Campbell, Lives of the Chancellors (1875) 63. See (1824) 35 EDINBURGH REv. 123, 410. 
$u^{\text {ute }}{ }^{s}$ making it a misdemeanor to set spring guns with intent to destroy human life or inflict grievous bodily harm upon a trespasser or other person coming in contact therewith.

The responsibility of an occupier of property for injuries to a trespasser or other person entering his property caused by spring guns was not considered in America until 1832. In the first case $^{\text {so }}$ in which the question was considered, the Supreme Court of Kentucky refused to give consent or dissent to the principles announced by the court in Ilott $v$. Willes therein, but its language seems to indicate that the English statute restrained the use of spring guns within "due and proper" bounds. In Jolizson $v$. Patterson, ${ }^{*}$ the Supreme Court of Connecticut repudiated the doctrine in toto as arising from the same spirit and being part of the same system as the game laws of England which have long been considered by many of their soundest jurists as an anomaly in their admirable system of municipal jurisprudence and as being utterly inapplicable to this country.

No American case has sanctioned the decision in Ilott 2 . Willes to its full extent. No court has gone further than to suggest that a trespasser, however harmless his purpose, is not entitled to recover for injuries inflicted by a spring gun which is set at a proper time and for the purpose of preventing a burglarious entry if he knows of the existence of the spring gun and nevertheless persists in his trespass.11 American courts are unanimous in holding that a possessor of property is not privileged to install spring guns or other mechanical devices intended or cal-

38 (1827) $7 \& 8$ Geo. IV, c. 18. The act applied not only to spring guns, but to any engine calculated to destroy human life or inflict grievous bodily harm upon a trespasser or other person coming in contact therewith and set with the intent of causing such harm, and contained a proviso excluding from its effect a spring gun, mantrap, or other engine set between sunset and sunrise in a dwelling house for the protection thereof.

In Wootton $v$. Dawlins $(1857$, C. A.) 2 C. B. (N. S.) 412 , the plaintiff came in contact with a wire which caused a loud explosion by which he was thrown down and slightly injured in his face and eyes. It was held that to entitle the plaintiff to recover under the Act of $7 \& 8 \mathrm{GeO}$. IV, c. 18 , it was not enough that the instrument was one calculated to cause alarm, and that there was no evidence to show that it was calculated to destroy human life or to inflict grievous bodily harm. As to the inapplicability of that Act to instruments calculated to kill or injure only trespassing animals, see Jordin v. Crump, supia note 36 .

so Gray v. Combs (1832, Ky.) 7 J. J. Marsh, 478.

to Supra note 36; cf. Simpson v. State (1877) 59 Ala. 1.

41 See Hooker v. Miller (1873) 37 Iowa, 613, 615 (spring gun Eet without notice to prevent trespassers from stealing owner's grapes; the plaintiff was a person entering to steal the grapes); Grant 2. Hass (1903) 31 Tex. Civ. App. 688. The Texas Code allowed the taking of life to prevent, intci alia, theft at night. An occupant of land setting spring guns to protect his melon patch is held to take the risk that the person coming in contact therewith intends theft, and to be responsible to a trespasser innocent of criminal intent. 
culated to destroy human life or inflict serious or grievous bodily harm for the protection of his property from a mere trespass, whether harmless or harmful.42 They are substantially unanimous in holding that an occupier of property is so far privileged to install such devices that he is not liable if they kill or maim a trespasser whom the occupier, had he been present in person, would have been privileged intentionally to kill or maim. Therefore, an occupier of property installing such devices is held not to be liable if the devices kill or maim a trespasser who enters with an actual felonious purpose and whose entry the occupier, were he present in person, could only prevent by killing or maiming him. ${ }^{43}$

There is some conflict in the decisions as to the privilege to use spring guns or other deadly devices to protect property from felonious entry where the entry, though felonious, involves no danger to life or limb. This conflict, however, is not based upon any distinction drawn between the privilege to kill or maim to prevent such an entry directly and in person and the privilege to do so indirectly by mechanical devices. It is based upon a difference of view as to the conditions under which the privilege to kill or maim to prevent a felony arises. ${ }^{44}$

42 State v. Becleham (1924) 306 Mo. 566, 267 S. W. 817 (defendant, setting a spring gun to protect his soft drink stand which contrined property worth less than six dollars, held guilty of manslaughter for the death of $\mathfrak{a}$ seventeen year old burglar); Pierce v. Commonwealth (1923) $135 \mathrm{Va} .635$, 115 S. E. 686 (defendant attached a spring gun to the door of his storo and the deceased, a policeman, was killed while "trying the defendunt's door." The court affirmed the jury's verdict of guilty of murder in tho second degree); State v. Green (1921) 118 S. C. 279 , 110 S. E. 145 (deceased, a trespasser, was killed by a spring gun set by the defendant in an unoccupied dwelling place and a verdict of guilty of murder in tho second degree was affirmed.)

43 Scheuerman $v$. Scharfenberg (1909) 163 Ala. 337, 50 So. 335 (burglar injured' by a spring gun while attempting to enter the defendant's store. Recovery was denied.); Gray v. Combs, supra note 39 ; cf. State v. Beckham, supra note 42; Pierce v. Commonwealth, supra note 42.

${ }^{44}$ In many states statutory crimes are labelled "felonies" or "misdemeanors" without any adequate discrimination between the moral or social culpability involved, or their effect upon their victims or society. The same crime may be termed a "felony" in one jurisdiction and a "misdemeanor" in another, and in the same jurisdiction the penalty attached to a misdemeanor may be as great or greater than that attached to many felonies. See Mikell, The Proposed Criminal Code of Pennsylvania (1923) 71 U. PA. L. REv. 99, 102.

To attach such importance to a term so loosely used is to make legal rights and duties dependent upon words, not upon facts or public policy. It is as vicious an exhibition of the bad effects of the "jurisprudence of concep* tions" as can well be imagined. The word is the thing. It of itself has a magic quality which compels legal results regardless of the facts or of the interest at stake. Is it not ridiculous to make matters of life and death depend upon the mere whim of the legislative draftsman and to subject a man to the risk of death merely because the crime which ho has committed is arbitrarily labelled a "felony" rather than a "misdemeanor"? 
In the majority of actual decisions, it is held that an owner of a building, forcible entry into which is either by common law or by statute made a felony, is so far privileged to use spring guns to prevent such entry that he is not liable to one entering under such circumstances as to make his entry felonious. ${ }^{s 5}$ On the other hand, there is a considerable body of dicta and at least one decision which restricts the privilege to use spring guns or other deadly devices to the protection of an occupied dwelling place $^{88}$ where experience has shown that the presence of a burglar

Blackstone gives as the reason for permitting "deadly" force to be used to prevent any felony-that all felonies are punishable by death; and therefore even if a person committing or attempting to commit a felong is killed, it is at most an anticipation of the penalty which he has incurred by his crime. See 4 Blackstone, Commentarics, $\approx 18 S$. If this wero ever valid in England, it has no validity in America today when the few felonies punishable by death rarely, if ever, include either common law or statutory burglary. It is more than doubtful if even in England, and at least in Blackstone's time, life might be taken to prevent every felony. Even if every felony were punishable by death, the privilege, when its purpose is to prevent a felony threatening injury to life or property, may be exercised not only when life or property is in actual danger, but also when it is reasonably, but mistakenly, believed to be so. Whatever may be said as to the justice of permitting the unofficial imposition of the death penalty upon actual felons, it is certainly an extreme penalty to attach to reasonably suspicious conduct to make the person unfortunate enough to incur suspicion fair game for one who, however reasonably, misinterprets his actions.

${ }_{45}$ Gray v. Combs, supra note 39; Scheuerman v. Seluarfenbcrg, supra note 43.

16 State v. Barr (1893) 11 Wash. 481, 39 Pac. 1080; of. Picreo 2. Commonwealth, supra note 42 ; and see $(1827) 7 \& 8 \mathrm{Geo}$. IV, c. 18 (reenacted substantially in (1851) $14 \& 15$ Vict. c. 19 , see. 4 and (1801) $5.1 \& 55$ Vict. ch. 69 , sec. 1 , whereby the setting of spring guns, except by night in a dwelling house for the protection thereof was made a criminal offense). See (1922) 70 U. PA. L. REv. 334.

Certain text writers have taken the time-honored statement that "every man's house is his castle" to justify a privilege to lill anyone whose intrusion into the actor's dwelling house cannot be prevented. See 1 Bishop, Criminal Law (7th ed.) sec. 858; 2 Wharton, Criminal Law (11th ed. 1912) sec. 634. These statements were based upon dicta in cases in which an accurate analysis of the fact showed that the intrusion was either felonious or one involving danger to life or limb of the inmates or both. State v. Bradley (1925, S. C.) 120 S. E. 240; Hall v. State (1914) 113 Arl. 454, 168 S. W. 1122; Young v. State (1905) 74 Neb. 346, 104 N. W. 807. Probably due to the influence of these dicta and the text writers' comment thereon, there are statutes which provide that a homicide is justifiable if necessary to protect real property from any intrusion (see Tex. Pen. Code, art. 680), or from an intrusion with any felonious purpose (see Utah Comp. Sts. 1917, ch. 8032), or from an intrusion which is felonious, violent or riotous (see 6 Parks Ga. Ann. Code, ch. 73), and for the purpose of assaulting or offering personal violence to the inmates of a dwelling house. See Ill. Crim. Code, ch. 148 (Hurd's Ill. Stat. 1899, p. 595). But apart from cases applying such statutes, it is the decided weight of authority, both of decision and reason, that the use of weapons or force dangerous to life and 
involves danger to life and limb. This view seems on the whole preferable. Whatever may have been the early common law, the privilege to kill to prevent a felony has for many generations been restricted both in England and America to felonies of an atrocious or violent character. It is quite possible that if the crime is so atrocious as seriously to affect the public interest even death may be inflicted for its prevention. If the crimes are of violence, such as were the great majority of early common law felonies, they are usually committed by such persons and under such circumstances as to threaten a very real risk of serious bodily injury to their victims.

Even though the entry into an unoccupied dwelling house was at common law a felony, 4 and entry into various other unoccupied buildings in which property is kept have been made felonies by statute, they are capable of affecting only the owner's interest in his property, real or personal. Such entries are, after all, made felonious not because of the disturbance which they cause to public order, but because they are serious invasions of property interests and perhaps even more probably because they have a superficial likeness to that time-honored category of felony, burglary. That such an entry is called a felony cannot change the fact that a privilege to kill to prevent it is, in its essence, a

limb is privileged, only if the actor reasonably believes that the threatened intrusion involves a danger to the life or limb of some inmate of the dwelling place. Bray v. State, supra note 3; State v. Countrymun (1806) 51 Kan. 815, 48 Pac. 137; State v. Patterson, supra note 3.

In the majority of jurisdictions, the traditional sanctity of the dwelling place as the owner's castle and haven of refuge is of legal significance only in that it permits one who is threatened with a murderous attack therein to use deadly weapons in self-defense without retreat, even though retreat could obviously be made with absolute certainty of safety and therefore must be made if he were attacked elsewhere, and that it probably permits an owner of a dwelling place to use such weapons if he cannot otherwise prevent himself from being dispossessed thereof. In ro J. J. Hussey, supra note 30 .

47 It is not easy to understand why the forcible entry upon an unoccupied dwelling even at night and with felonious intent was held to constitute $a$ burglary at common law. There is a fundamental distinction between such an entry by night and a similar entry by day. The former is not only less capable of detection and safe prevention, but it involves a danger of bodily harm to the inmates far greater than that threatened by the lattor. But if the dwelling place is unoccupied, there are no inmates whose life or limb can be imperilled. Indeed, it is not easy to distinguish even a nocturnal entry upon an unoccupied dwelling house from a nocturnal entry upon any other building in which the chattels are kept. The fact that the dwelling house is unoccupied eliminates all danger to life and limb of the inmates. All that remains is the possessor's proprietary interest in the building and chattels, which is no greater than the similar interest of the possessor of a warehouse stored with goods. The peculinr sanctity which immemorial tradition attaches to a dwelling place, however, may account for the distinction between an unoccupied dwelling house and other 
privilege to kill or maim for the purpose of protecting the buildings and chattels therein from injury, destruction or theft.:3

It is difficult to reconcile so broad a privilege with the admitted rule that there is no privilege to kill or maim merely to preserve from no matter how serious an invasion any interest in property, other than the possession of a dwelling place, if the property is so situated that its invasion does not constitute a statutory felony. ${ }^{43}$

buildings outside the curtilage of the dwelling place. But it may be suggested that it is possible that the felonious entry upon an unoceupied dwelling house was held to be a burglary because courts had lost sight of the reason for regarding a nocturnal entry upon a dwelling place as more eriminal than an entry by day, and regarded the question as elosed by the fact that the premises fell within the traditional term "dwelling place."

There appears in the criminal law a tendency to regard the terms of a common law definition as having the same force as the statutory definition of a crime, and therefore to regard the question of the eriminality of an act as depending entirely upon whether the facts fall within the letter of the definition. This tendency is more usually apparent in cases where a court is reluctant to extend the scope of a capital crime beyond that which the strict letter of the definition requires. In this case, however, the letter of the definition seems to be applied to malie capital an offense which otherwise would be at most a misdemeanor.

4s In the case of Scheucrman v. Scharfonbcrg, supia note 43 , the plaintiff, while entering the defendant's store for the purpose of stealing the goods kept therein, was shot by a spring gun set for its protection. The court, in holding that the plaintiff could not recover, called attention to the fact that the burglary of a storehouse in which goods are liept for sale or in deposit is made a felony by Ala. Code, 1907, see. 6110 (4417), but also says, "a man's place of business (as the defendant's store in this case) is pro hac vice his dwelling, and he has the same right to defend it against entries such as burglary as he has to protect his dwelling place", citing Jones v. State (1884) 76 Ala. 8, 16.

In Jones $v$. State, supra, the only point decided was that a man attaelied with deadly force in his store might stand his ground, as he might if attacked in his home, and defend himself against it with deadly weapons even though he had a clear and obvious opportunity of safe retreat. In the case of Gray v. Combs, supra note 39, the plaintiff's slave was shot by a spring gun while attempting to enter the defendant's warehouse for the purpose of stealing the goods therein. The language of the court appears to favor a very broad privilege to kill or attempt to kill for the protection of property; but the opinion is based upon the fact that an entry into such a building was by statute made a felony if perpetrated by a free white man, although it was only a statutory misdemeanor if done by a slave.

49 One of the methods which courts have used in extending the privilege to kill for the protection of property is by liberally construing the word "dwelling". Thus in Cnited States 2. Gillinm (1882, D. C.) 25 Fed. Cas. 15205a, the defendant was indicted for the murder of the deceased who was killed by the defendant's spring gun while entering the goose house of the defendant in the night time with intent to steal. The court held that the goose house was within the "curtilage" and so the lilling was justified. 
Under the view which restricts the privilege to the protection of a building used as a dwelling place, the privilege becomes merely a form of the more general privilege to use deadly force to protect the actor and others from death or serious bodily injury usually threatened by felonious intrusions. ${ }^{50}$ The traditional sanctity of a dwelling house allows any inmate to meet the dangerous invader at the frontier and check the danger then and there without the necessity of retreating or waiting until the intruder attempts to make so immediate an attack as he would be required to do were a similar danger threatened elsewhere. ${ }^{61}$

Upon one point the authorities are unfortunately vague. If an occupier is present in person, he is privileged to use "deadly" force not only to prevent an intrusion which is, in fact, burglarious and which, in fact, he cannot otherwise prevent; but he is also privileged to use deadly force to prevent an intrusion which he honestly, though mistakenly, believes to be such. ${ }^{\text {t2 }}$ So too, if he employs a servant or other deputy to protect his property in his absence, he is not liable to an intruder whose entry the deputy honestly, but mistakenly, believes to be burglarious and impossible to prevent save by deadly force.

In State v. Green, ${ }^{63}$ the only case which has expressly ruled upon the matter, it is held that an occupier setting spring guns for the protection of his property, or indeed of his personal security, is not relieved from liability to an intruder who, in fact, is not a burglar, but whose conduct in the light of the surround-

50 This does not mean that a man may not defend himself by force which threatens death or serious bodily injury to his assailant against an attack which threatens similar injury to him, even though his assailant's threat to kill or wound him is conditioned upon his refusal to permit the assailant to enter his dwelling or to rob him of his property. In such a case ho has an obviously safe opportunity of avoiding the necessity of using such solfdefensive force by permitting the threatener to enter his dwelling place or take his property. But while a man must normally avoid the necessity of using dangerous self-defensive force even to the point of sacrificing his dignity by retreat, he is not compelled to relinquish either the possession of his chattels or the exclusiveness of the possession of his dwelling house. In re J. J. Hussey, supra note 30 . So a man may not kill or maim to protect himself even against the most oppressive of unlawful arrests which milder methods of resistance are incapable of preventing. But he may dofend himself against deadly violence used to accomplish his arrest oven though the threat of violence is obviously conditioned upon his refusal to submit, and so he could avert it without danger to his bodily security by ${ }^{\circ}$ submission and therefore need not protect himself from injury by force. Miers v. State (1895) 34 Tex. Cr. App. 161, 29 S. W. 1074; Perdue v. Stato (1908) 5 Ga. App. 821, 63 S. E. 922; Coleman v. State (1904) 121 Ga. 594, 49 S. E. 716. But see State v. Cantieny (1885) 34 Minn. 1.

${ }^{61}$ Brinkley v. State (1889) 89 Ala. 34, 8 So. 22. See Beale, Retreat From Murderous Assault (1903) 16 HARv. L. REv. 567, 569.

62 Carroll v. State (1853) 23 Ala. 28; cf. Harris v. State (1891) 96 Ala. 24,11 So. 255 . See 1 Wharton, op. cit. supra note 46.

${ }_{53}$ (1921) 118 S. C. 279,110 S. E. 145. 
ing circumstances would have justified the occupier, had he been present, in believing him to be so.

At first glance it is difficult to perceive why the occupier should be protected if his human deputy reasonably, though mistakenly, misinterprets the intruder's conduct, and should not be protected if the inanimate devices which he has placed there to act in his stead injure the trespasser under circumstances identically similar to those which would have given him a privilege to do so.

But as the court in State $v$. Green points out, if the occupier had been present in person and had killed the "intruder," it would have been necessary for him to show not only that the circumstances were sufficient to justify a person of ordinary firmness and reason in believing that he was in danger of losing his life or of suffering serious bodily harr, "but that he himself so believed." The requirement that the occupier, or his human deputy must so believe, is a very real protection to actually innocent and harmless intruders. Unless the circumstances and the intruder's conduct is such that no man, reasonable or unreasonable, could help but misinterpret his purpose, there always remains the chance that a human being present at the spot, nothwithstanding the suspicious circumstances, would realize the true state of affairs and recognize the intruder as one whom he would not be justified in killing or wounding. On the whole, therefore, it would seem that the principle announced in State $v$. Gitecin is sound.

Were it not for the fact that great latitude is allowed to a householder in his dealings with an actual or supposed burglar, it would seem that one setting a spring gun to protect his property should also be liable if, in fact, the entry of even a burglarious intruder could have been prevented otherwise than by the operation of the gun.51 Granting, however, that the intruder is, in fact, a burglar, there is less reason to be tender of his rights and interests. If the interest in the security of the inmates of an occupied house is regarded as of sufficient value to justify protection by spring guns, the privilege to use them should not be so restricted as to make their use ineffective or a source of unreasonable responsibility. It is difficult to imagine a spring

54 "If defendant had been personally present and lilled deceased under the circumstances aforesaid, in order to sustain his plea of justification ho would have been compelled to satisfy the jury that he had used no more force than was reasonably necessary in repelling the assault of deceased in attempting to enter his premises to commit the crime of burglary, if such was his intention. . - Again if the defendant had been personally present, and had killed the deceased with said gun, under the foregoing circumstances, the jury, in passing upon the plea of justification, might have concluded that there was no reasonable necessity for lilling deceased until the latter had, at least, entered the building." Railey, C., in Stato v. Beckham (1924) 306 Mo. 566, 575, 267 S. W. 817, 818. 
gun that will repel a burglar which may not act prematurely, or upon a burglar who might be excluded by other and less dangerous means. While the law should in every way safeguard

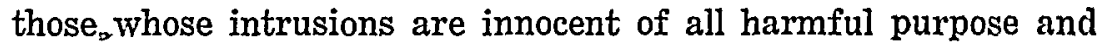
even those whose intrusions, though likely to do harm, do not threaten injury either to life, limb or property so serious as to warrant deadly force in repelling them, there is no reason to protect actually dangerous intruders by restrictions which deprive the householder of the possibility of effective protection.

In all of the cases in which a possessor of property has been held liable to an intruder injured by a spring gun, the intruder has been one whom the occupier, had he been present in person and known the facts, would not have been justified in killing or wounding; and in all of them the property protected from intrusion was either not a dwelling house, or if a dwelling house, was unoccupied. In them the privilege to use such devices without liability to even a criminal intruder was based either upon the fact that the building was a warehouse or a business office and as such to be regarded as substantially the same as a dwelling house, or a criminal entry upon such buildings was made a statutory felony, often expressly called a burglary.

It may be that it is proper to require one who is privileged to use "deadly" devices for the protection of such property even against felonious entries to run the risk that it will operate only upon criminal intruders whose intrusions the owner might personally repel by deadly force. It does not necessarily follow that the use of such devices for the purpose of protecting the lives of inmates of an occupied dwelling place should be exercised at the same risk. After all, the situation is closely cognate to the case where a man who is threatened with a murderous attack in lawful self-defense, by deadly force directed against the assailant and not intended to injure bystanders, wounds a bystander.

The spring gun is intended to injure only burglars. The time during which it is set is such that the likelihood of non-burglarious intrusion is extremely remote. In such a case, it would seem that there is room to argue that there should be no greater liability for injuries done to the unforeseeable though innocent intruder than there is to a person suddenly appearing within the range of a carefully fired, but none the less misdirected, bullet shot in self-defense against a murderous assailant. There is, however, no basis either in decision or in judicial dicta for such a distinction. After all, the decisions which hold the occupier liable are in jurisdictions which make no distinction between the privilege to use deadly force, either directly or indirectly, to repel felonious intrusions which are dangerous to life, and those which are dangerous only to property. It seems likely, therefore, that those jurisdictions which permit the occupier in person, or by 
mechanical devices, to apply deadly force to only those felonious intruders upon an occupied dwelling house, whose presence therein involves dangers to the life of its inmates, will accept these decisions at their face value and will hold that the privilege to set spring guns for the purpose of protecting occupied dwellings is subject to the risk of responsibility for injury done thereby to persons who intrude without felonious intent. 